\title{
THE EFFECT OF FISHING BASIN CONSTRUCTION ON THE BEHAVIOUR OF A FOOTBRDGE OVER THE PORT CHANNEL
}

\author{
Lukasz Pyrzowski \\ Mikołaj Miśkiewicz \\ Jacek Chróścielewski \\ Gdansk University of Technology, Faculty of Civil and Environmental Engineering
}

ABSTRACT

\begin{abstract}
The paper analyses possible causes of failure of the rotating footbridge over the Ustka port channel. In July, 2015, strange behaviour of this object was observed in the form of excessive vibrations of bridge platform suspension rods, with the accompanying acoustic effects. A preliminary geotechnical analysis has revealed that this destructive effect was caused by the nearby construction works, namely construction of a fishing basin and communication routes in the area close to the bridge, which affected the bridge lashing rod foundation settings. Ground vibrations generated by certain construction activities were likely to have direct impact on decreasing the bearing capacity of these rods and increasing the susceptibility od the piles to extraction. After detecting the above problems in bridge operation, its geodetic monitoring was started. The data recorded during this monitoring, along with the results of force measurements in the rods, have made the basis for a series of numerical simulations, performed in the Finite Element Method (FEM) formalism. The bridge structure was analysed in the conditions defined as the emergency state. Extreme efforts of bridge elements and its dynamic characteristics were examined. A possible source of strange behaviour of the footbridge during its operation which was recognised during these simulations was the coincidence of the global natural frequency of the entire bridge structure with local vibrations of suspension rods, at the frequency approximately equal to $1 \mathrm{~Hz}$. This situation was likely to lead to the appearance of the so-called internal resonance phenomenon. As a final conclusion of the research, recommendations were formulated on possible object oriented corrective actions.
\end{abstract}

Keywords: footbridge, port basin, failure

\section{INTRODUCTION}

The analysed footbridge (Fig. 1.) is situated in the area of Port Morski w Ustce Sp. z o.o., Pomorskie voivodeship. Its function is to pass the pedestrian and cycle traffic over the port channel being the mouth of the Słupia river. The rotating structure of the bridge makes it possible to close the passage temporarily to allow the watercraft to enter or leave the port [19-22].

The footbridge was constructed in accordance with the design [11] and positively passed load tests [14], which testified that all design assumptions had been fulfilled. The object was opened for public use in December, 2013, and until June, 2015, it operated without failure. On July 3, 2015, the CEO of Port Morski w Ustce Sp. z o.o. informed HYDRONAVAL Sp. z o.o., the contractor, about worrying symptoms in footbridge behaviour, observed as excessive vibrations of bridge suspension rods accompanied by acoustic effects. As the object guarantor, the contractor immediately asked for temporary closing of the bridge.

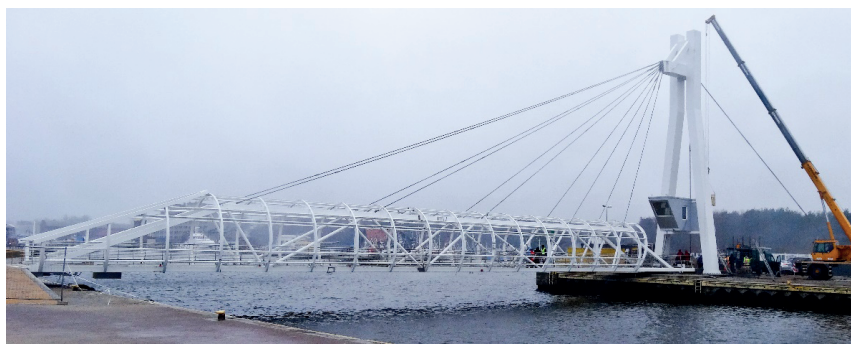

Fig. 1. Rotating footbridge for pedestrians over the Ustka port channel (configuration W1a)

As a result of experts' activities [2], it was concluded that the investments carried out by the Ustka Commune in the area close to the footbridge had a considerable effect on its state. It was recognised that the construction works related to 
the construction of the fishing basin and the communication routes, which were carried out in close proximity of the bridge, had changed ground parameters in the area surrounding the bridge foundations. This effect related to dynamic immersion of sheet pile walls at a distance of only $13 \mathrm{~m}$ from one of bridge lashing rod anchor blocks. The final effect of the carried-out construction works was the increased susceptibility of the piles to extraction $[5,6]$.

The article presents results of the analyses which aimed at clarifying possible causes of the footbridge failure. The data coming from geodetic measurements and those recorded in force measurements in the rods made the basis for a series of numerical simulations performed in the Finite Element Method (FEM) formalism. Taking into account the measured data has made it possible to evaluate the current static effort of the bridge and the dynamic behaviour of both its individual elements and the structure as a whole. Then, based on the obtained results, calculations were made to indicate possible causes of bridge behaviour change. Finally, after identifying the most likely failure causes, a simulation was performed to suggest corrective actions which would allow to reinstate correct operation of the bridge.

\section{CHARACTERISTICS OF THE OBJECT}

The object of analysis is a steel rotating suspended footbridge structure with the span in the form of truss (Fig. 2). The pylon jest fixed in the base and stabilised by two lashing rods anchored by their foundations in the ground. From the pylon side, the support for the suspended span is provided by the rotating mechanism, while from the other side it is supported by a system of hydraulic cylinders taking the form of sliding articulated supports. The bridge platform is a steel orthotropic plate. Beside the truss girders, steel elliptic clamps welded to the truss chords are used as lateral stiffeners of the span. Span suspension and lashing rods are made of a system of structural bars.

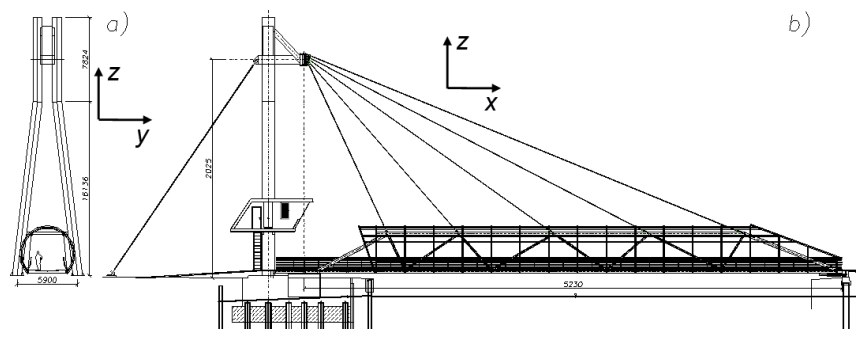

Fig. 2. General view of the footbridge in configuration (W1)-locked, open for pedestrian traffic: a) cross section, $b$ ) south-side view; $X Y Z$ - the reference coordinate system used in the analysis

At the top of the pylon, pull rod anchors are fixed to the rotating head, which protrudes with respect to the bridge opening axis in such a way as to ensure passive movement of suspension rods to follow the motion of the span. The pylon lashing rods are fixed in anchor blocks embedded in the ground. The bridge is set on steel pipe piles $508 / 10 \mathrm{~mm}$ with open bottom. Rotating the bridge structure between the operating state (open for pedestrians) and the closed state (open navigation channel) is executed using the mechanism installed under the span platform $[9,13]$.

The footbridge was designed for the load caused by a crowd of pedestrians, $\mathrm{q}=4 \mathrm{kN} / \mathrm{m}^{2}$ acc. to [15], and ambulance travel. The supporting structure was made of steel S355J, while the suspension and lashing rods were made of steel DS520.

Basic parameters of the footbridge are: span $52,3 \mathrm{~m}$, pylon height $23,96 \mathrm{~m}$, total width $5,38 \mathrm{~m}$, total height $4,43 \mathrm{~m}$, slope angle with the obstacle $90^{\circ}$.

\section{GEODETIC MEASUREMENTS}

In the case of three independent hard construction works, i.e. construction of the footbridge, the fishing basin, and the communication routes, carried out in the areas close to each other, the zones of their mutual influence had to be determined $[5,6]$. Unfortunately, this task was not done. In particular, initial geodetic measurements and object monitoring in the area influenced by the construction works were not performed. The geodetic monitoring of the bridge was only started after its incorrect behaviour had been reported. The parameters recorded in the measurements included: pylon deviation from vertical, distances between lashing rod anchor points, and height ordinates of pylon and lashing rod foundations. These parameters were measured in all four positions of the bridge span: opened/locked - W1, opened/unlocked - W1a, closed/locked - W2, and closed/ unlocked - W2a.

From the point of view of bridge operation analysis, it was the measurements performed at points situated at pylon top (Tab. 1) which turned out to be most valuable, as similar data recorded on December 12, 2013, i.e. before the failure were also available. The calculated differences between them made the basis for evaluating the cumulated effect of all construction works. It turned out that during this time, in similar environmental conditions, the top of the pylon in position W1a moved towards the span by the distance Ux of about $10 \mathrm{~mm}$ (Tab. 1).

Tab. 1. Deviation of pylon top from vertical and changes of foundation height ordinate. Points situated at south side

\begin{tabular}{|c|c|c|c|c|c|c|c|c|}
\hline & \multicolumn{3}{|c|}{$\begin{array}{c}\text { Deviation of pylon top } \\
\text { from vertical, } \\
\text { Ux [mm] }\end{array}$ Span } \\
position & \multicolumn{4}{|c|}{$\begin{array}{c}\text { Change of lashing rod } \\
\text { Uz [mm] }\end{array}$} \\
\cline { 2 - 9 } & $\begin{array}{c}2013 \\
10.12\end{array}$ & $\begin{array}{c}2015 \\
07.08\end{array}$ & $\begin{array}{c}2015 \\
09.23\end{array}$ & $\begin{array}{c}2015 \\
11.24\end{array}$ & $\begin{array}{c}2013 \\
10.12\end{array}$ & $\begin{array}{c}2015 \\
07.08\end{array}$ & $\begin{array}{c}2015 \\
09.23\end{array}$ & $\begin{array}{c}2015 \\
11.24\end{array}$ \\
\hline W1 & - & 87 & 81 & 79 & - & 2334 & 2339 & 2340 \\
\hline W1a & 75 & - & 88 & 85 & - & - & - & - \\
\hline W2 & - & 72 & 61 & 57 & - & 2334 & 2339 & 2340 \\
\hline W2a & 54 & - & 64 & 61 & - & - & - & - \\
\hline
\end{tabular}

Due to the fact that they were not monitored from the very beginning of bridge operation, the changes of the pylon and lashing rod foundation height ordinate are time-limited and 
only include the values recorded in a relatively short time interval, from July to November, 2015. It is noteworthy that construction works in the area close to the footbridge were conducted long before formal failure reporting, i.e. before the first monitoring measurement. The measurements performed in bridge position $\mathrm{W} 1$ have revealed that during this short time of monitoring the foundation of the right lashing rod moved up (Uz) by $6 \mathrm{~mm}$ (Tab. 1).

\section{FORCE MEASUREMENTS IN RODS}

In order to evaluate current effort states of individual footbridge elements, forces were measured in the pull rods composing the bridge suspension and in the lashing rods. The measurements were made using the vibration method [23] and the 15-channel set for vibration monitoring in building structures WE 3001a, cooperating with three-axis accelerometers MEMS. The forces in the rod elements were evaluated by measuring their free vibrations. Along with local vibration frequencies, the measurements performed on selected rods made it possible to work out the characteristics corresponding to global movements of the entire structure. The adopted rod labelling in the footbridge structure is given in Fig. 3.

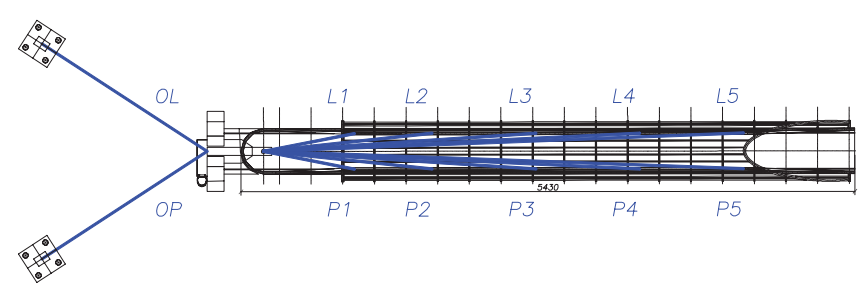

Fig. 3. Top view of the footbridge structure - rod labelling

The identified absolute values of normal forces $\mathrm{N}$ in the lashing rods and the longest suspension rods are given in Tab. 2, along with the reference to their design values.

\section{FEM CALCULATIONS}

Computer simulations of the state of the structure were performed in the FEM environment within the linear-elastic range of material and the geometrically nonlinear range of the structure with imperfections $[1,3,4,7,8,10,17,18]$. In the adopted FEM models (Fig. 4) the following finite elements were used:

a) 1-dimensional, 2-node spatial rod (beam) finite elements of Timoszenko type with eccentricity - used to model: pylon, grate, elliptic clamps, ribs and traverses of orthotropic platform plate, piles (8632 elements in the model);

b) 2-dimensional, 4-node sheet elements of TimoszenkoReissner type - used to model: the orthotropic platform plate (7627 elements in the model);

c) 1-dimesional, 2-node spatial elements of rod-grate type used to model: the footbridge structure suspension system (360 elements in the model).

The boundary conditions for the support took into account the foundation/ground cooperation and the conditions resulting from locking/unlocking of the bridge span structure on the river bank opposite to the pylon.

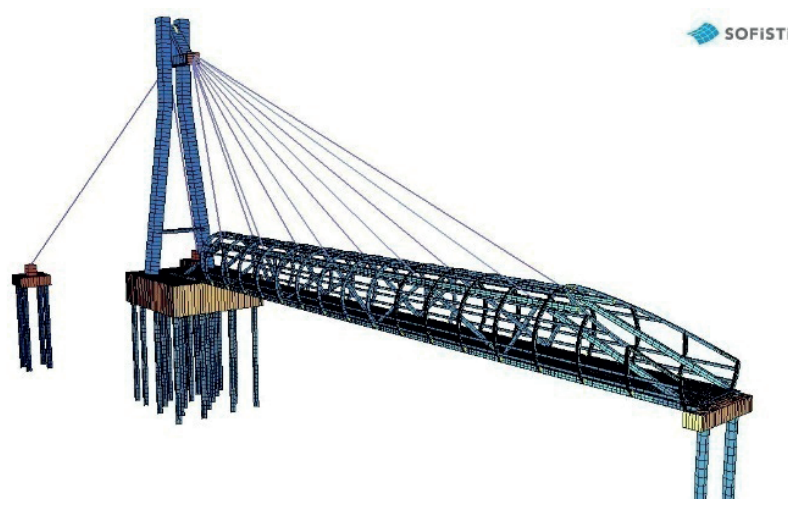

Fig. 4. Visualisation of the FEM model used in the analysis

Tab. 2. Comparing measured and designed normal forces $N$ in rods

\begin{tabular}{|c|c|c|c|c|c|c|c|c|}
\hline $\begin{array}{c}\text { Span } \\
\text { position }\end{array}$ & \multicolumn{2}{|c|}{ W1 } & \multicolumn{2}{c|}{ W1a } & \multicolumn{3}{c|}{ W2 } & \multicolumn{2}{c|}{ W2a } \\
\hline Force & Measurement & Design & Measurement & Design & Measurement & Design & Measurement & Design \\
\hline Rod & $\mathrm{N}[\mathrm{kN}]$ & $\mathrm{N}[\mathrm{kN}]$ & $\mathrm{N}[\mathrm{kN}]$ & $\mathrm{N}[\mathrm{kN}]$ & $\mathrm{N}[\mathrm{kN}]$ & $\mathrm{N}[\mathrm{kN}]$ & $\mathrm{N}[\mathrm{kN}]$ & $\mathrm{N}[\mathrm{kN}]$ \\
\hline OL & 426 & 768 & 522 & 748 & 74 & 124 & 72 & 97 \\
\hline L5 & 85 & 145 & 113 & 140 & 78 & 33 & $-\cdots$ & 140 \\
\hline OP & 483 & 768 & 579 & 748 & 181 & 213 & 223 & 326 \\
\hline P5 & 68 & 145 & 92 & 140 & 78 & 44 & $-\cdots$ & 136 \\
\hline
\end{tabular}

Symbol „---, means that the measured result (in span position W2a - closed/unlocked) ambiguously indicates the free vibration frequency. It is noteworthy that the forces recorded in the measurements differ much from those assumed by the designer [11] and introduced to the structure by the rod rigging producer.
The parameters calculated in the steady-state variant included: extreme internal forces, efforts in complex state according to the $\mathrm{HMH}$ hypothesis, and structure displacements, as functions of the acting loading scenarios. The bridge behaviour was verified under the load state as in [15]: characteristic with respect to the useless state of the structure, in order to determine basic (P) and additional 
(PD) forces in the rods. The dynamic calculations allowed to evaluate global and local (with respect to particular rods) free vibration frequencies and modes.

\section{CURRENT STATE OF THE FOOTBRIDGE STRUCTURE}

The collected measurement data set was used, along with model updating techniques, to work out a numerical model reflecting the current state of the footbridge structure. The compliance of the theoretical description with the really measured rod forces and pylon displacements was analysed. The identified differences between the forces recorded in the measurements and those obtained from FEM calculations were considered acceptable from the point of view of the range and goal of the performed analysis. The adopted numerical model was positively validated as correctly modelling the real behaviour of the footbridge structure. Tab. 3 collates representative pylon displacements.

Tab. 3. Measured and calculated pylon top displacements (in useless state)

\begin{tabular}{|c|c|c|c|}
\hline Span position & $\begin{array}{c}\text { Measurement } \\
{[\mathrm{mm}]} \\
2015.09 .23\end{array}$ & $\begin{array}{c}\text { Measurement } \\
{[\mathrm{mm}]} \\
2015.11 .24\end{array}$ & $\begin{array}{c}\text { Calculation } \\
{[\mathrm{mm}]}\end{array}$ \\
\hline W1 & 81 & 79 & 81 \\
\hline W1a & 88 & 85 & 86 \\
\hline W2 & 61 & 57 & 57 \\
\hline W2a & 64 & 61 & 61 \\
\hline
\end{tabular}

As the next step, extreme efforts of footbridge elements in the current state were evaluated. For this purpose, calculations were performed for a combination of loads, according to the basic and additional load system [15]. The results are collated in Tab. 4. They should be related to the parameters of steel S355J used as material for the structure of the footbridge.

Tab. 4. Extreme efforts of footbridge structure elements in current state, stresses acc. to $\mathrm{HMH}[\mathrm{MPa}]$

\begin{tabular}{|c|c|c|c|c|}
\hline Quantity $\backslash$ Scheme & W1 & W1a & W2 & W2a \\
\hline Pylon & 101 & 96 & 187 & 249 \\
\hline Lattice girder & 169 & 55 & 164 & 166 \\
\hline Span rings & 322 & 53 & 205 & 181 \\
\hline Ring stringers & 354 & 45 & 194 & 75 \\
\hline Platform, traverse & 94 & 24 & 78 & 81 \\
\hline Platform, ribs & 96 & 39 & 68 & 64 \\
\hline Platform, plate & 153 & 60 & 150 & 150 \\
\hline
\end{tabular}

The simulation results reveal that despite the anomalies observed in the dynamic behaviour of the footbridge, the static effort state of its individual elements, expressed by stresses in complex effort state, is correct and does not cause anxiety with respect to their potential failure.

To illustrate the dynamic response of the structure in its current state, global free vibration frequencies (see Tab. 5) and modes were determined numerically. The results of both the in-situ measurements and the numerical simulations performed in FEM environment indicate that for the unlocked structure, schemes W1a and W2a, global free vibration frequencies are observed at the approximate frequency level of $1 \mathrm{~Hz}$.

Tab. 5. Three first global free vibration frequencies of the footbridge structure - results of numerical calculations

\begin{tabular}{|c|c|c|c|}
\hline Span position & $f_{1}[\mathrm{~Hz}]$ & $f_{2}[\mathrm{~Hz}]$ & $f_{3}[\mathrm{~Hz}]$ \\
\hline W1 & 3,03 & 3,41 & 5,31 \\
\hline W1a & 0,96 & 1,42 & 2,64 \\
\hline W2 & 3,05 & 3,38 & 5,23 \\
\hline W2a & 0,96 & 1,15 & 2,66 \\
\hline
\end{tabular}

It is noteworthy that some local free vibration frequencies of rods, which were measured for force evaluation, are also situated close to $1 \mathrm{~Hz}$. Putting those two facts together justifies formulating the conclusion that it is the compliance of these above frequencies which most likely leads to the appearance of the internal resonance phenomenon. This internal resonance, in turn, can lead to coupling of global free vibration frequencies of the footbridge structure with local frequencies of the longest platform suspension rods. This coupling can cause large-amplitude vibrations, accompanied by characteristic acoustic effects observed on the object during footbridge opening/closing.

\section{THE EFFECT OF LASHING ROD ANCHOR BLOCK DISPLACEMENT ON FOOTBRIDGE OPERATION PARAMETERS}

Mistuning of the system of tension forces in the suspension and lashing rods, along with the measured slipping of the lashing rod foundation block out of the ground, suggest the need for performing a numerical simulation of parametric analysis type to assess the effect of possible further foundation displacement on the redistribution of internal forces in the structure. This simulation was made for the bridge position variant W1 and the so-called useless state of the structure as the initial phase. The controlled variable in the analysis was the displacement parameter which represented vertical upward movement of the right lashing rod foundation. The control parameters which were considered as representative for problem illustration were the following: force in the right lashing rod, force in the longest span suspension rod, and pylon displacement.

The vertical displacement of the foundation which was recorded during geodetic monitoring increased by $6 \mathrm{~mm}$. However, the results of the performed simulation suggest that the real displacement which possibly took place from the beginning of footbridge operation is of the order of 19 $\mathrm{mm}$, as only for this value the calculated control parameters reach the levels corresponding to the in-situ measurements (see Fig. 5). It is also noteworthy that in the real situation, the analysed foundation was likely to move in an uncontrolled 
manner also in the horizontal direction, which could affect the obtained results.



Fig. 5. Changes of control parameters: force in the right lashing rod (OP), force in the longest right suspension rod (P5), and horizontal pylon displacement $(U x)$ as functions of vertical upward displacement of the right lashing rod foundation

\section{CONCLUSIONS}

Restoring correct operation and safe use of the footbridge over the Ustka port channel requires corrective actions, which should aim at eliminating damages caused by the construction of the fishing basin and communication routes in the area close to the bridge. These corrective actions should consist, first, in stabilising the most vulnerable lashing rod foundations and then, in adjusting tension forces in the rods to bring them to the target state with the vertical axis of the rotating head at the top of the pylon. After force adjustment in the rods, the internal resonance phenomenon, being the effect of coupling of global and local frequencies at the level of about $1 \mathrm{~Hz}$, should disappear. However, due to the theoretical nature of the performed analysis, the process of force adjustment in the rods should be followed by relevant examination, making a basis for formulating final conclusions relating to the dynamic response of the object. Additionally, due to incorrect operation of the system, being the result of changes in ground conditions in the footbridge foundation area, during the first year of further bridge operation after its release to service, permanent Structural Health Monitoring System (SHT) is to be installed, according to [16], along with the numerical simulation module which will monitor safe operation of the footbridge $[12,24]$.

\section{BIBLIOGRAPHY}

1. Bielewicz E, Górski J.: Shells with random geometric imperfections simulation - based approach. International Journal of Non-Linear Mechanics, 37(4-5), 2002, pp. 777-784.

2. Bolt A., Horodecki G., Cudny M., Wilde K., Chróścielewski J., Miśkiewicz M., Pyrzowski Ł.: Technical expertise concerning possible causes of failure of the openable footbridge structure over the Ustka port channel (in Polish). Gdansk University of Technology, 2015.
3. Burzyński S., Chróścielewski J., Witkowski W.: Geometrically nonlinear FEM analysis of 6-parameter resultant shell theory based on 2-D Cosserat constitutive model. ZAMM-Zeitschrift fur AngewandteMathematik und Mechanik 96 (2), 2015, pp.191-204

4. Chróścielewski J., Witkowski W.: Four-node semi-EAS element in six-field nonlinear theory of shells. International Journal for Numerical Methods In Engineering 68(11), 2006, pp. 1137-1179.

5. Horodecki G.A.: Environmental interactions of deep excavations in urbanised areas (in Polish). Inżynieria Morska i Geotechnika 3, 2016.

6. Horodecki G.A., Bolt A.F., Dembicki E.: Geotechnical problems in design and execution of enclosed excavations (in Polish). Inżynieria i Budownictwo 12, 2002, pp. 683-686.

7. Iwicki P., Tejchman A., Chróścielewski J.: Dynamic FE simulations of buckling process in thin-walled cylindrical metal silos. Thin-Walled Structures 84, 2014, pp. 344-359.

8. Kaliński K.: The finite element method application to linear closed loop steady system vibration analysis. International Journal of Mechanical Sciences 39 (3), 1997, pp. 315-330.

9. Kaliński K. J., Mazur M., Kaliński K. J., Mazur M.: Optimal control at energy performance index of the mobile robots following dynamically created trajectories. Mechatronics 37, 2016,pp. 79-88.

10. Kreja I., Schmidt R.: Large rotations in first-order shear deformation FE analysis of laminated shells. International Journal Of Non-Linear Mechanics 41(1), 2006, pp.101-123.

11. Łukaszewicz A.: Design of openable footbridge over the Ustka port channel (in Polish). HYDRO-NAVAL Sp. z o.o.: 2013.

12. Mariak A., Miśkiewicz M, Meronk B., Pyrzowski Ł., Wilde K.: Reference FEM model for SHM system of cable-stayed bridge in Rzeszów. Advances in Mechanics: Theoretical, Computational and Interdisciplinary Issues, Taylor \& Francis Group, London 2016, pp. 383-387.

13. Mikielewicz J., Mikielewicz D.: A simple model of circular hydraulic pump. International Journal of Heat and Mass Transfer52(1), 2008, pp. 17-21.

14. Miśkiewicz M., Wilde K., Chróścielewski J., Pyrzowski Ł. et al.: Report of test loads of the openable footbridge over the Ustka port channel (in Polish). Gdansk University of Technology, 2013.

15. PN-85/S-10030 Bridge objects. Loads (in Polish). 
16. Ordinance of the Minister of Maritime Economy of 23 October, 2006, on technical conditions of use and detailed scope of examination of marine hydro-technical structures (in Polish).

17. Sabik A., Kreja I.: Large thermo-elastic displacement and stability FEM analysis of multilayered plates and shells. Thin-Walled Structures 71, 2013, pp.119-133.

18. Siemiątkowski M., Przybylski W.: Simulation studies of process flow with in-line part inspection in machining cells. Journal of Materials Processing Technology 171 (1), 2006, pp. 27-34.

19. Szłapczyński R.: Evolutionary Sets of Safe Ship Trajectories Within Traffic Separation Schemes. Journal of Navigation 66 (1), 2012, pp. 65-81.

20. Szłapczyński R.: Evolutionary Planning of Safe Ship Tracks in Restricted Visibility. Journal of Navigation 68 (01), 2015, pp. 39-51.

21. Szłapczyński R., Szłapczyńska J.: Customized crossover in evolutionary sets of safe ship trajectories. International Journal of Applied Mathematics and Computer Science 22 (4), 2012, pp. 999-1009.

22. Szłapczyński R., Szłapczyńska J.: On evolutionary computing in multi-ship trajectory planning. Applied Intelligence 2011, pp. 1-20.

23. Topolewicz K., Topolewicz M., Rucka M., Wilde K.: Vibration method for evaluating forces in suspension members illustrated by the case Gdansk overbridge (in Polish). Wrocławskie Dni Mostowe, 2014, pp.439-446.

24. Wilde, K., Miśkiewicz, M., Chróścielewski, J.: SHM System of the Roof Structure of Sports Arena „Olivia”. Structural Health Monitoring 2013 - Vol. II, Pennsylvania 2013, pp. 1745-1752.

\section{CONTACT WITH THE AUTHORS}

\author{
Łukasz Pyrzowski \\ Mikołaj Miśkiewicz \\ Jacek Chróścielewski \\ Gdansk University of Technology \\ Faculty of Civil and Environmental Engineering \\ 11/12 Narutowicza St. \\ 80 - 233 Gdańsk \\ Poland
}

